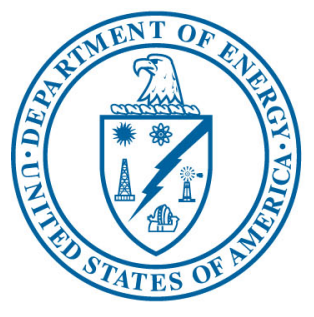

U.S. Department of Energy

Idaho Operations Office

\title{
Mission Need Statement: Idaho Spent Fuel Facility Project
}

September 2007 


\section{Mission Need Statement: Idaho Spent Fuel Facility Project}

September 2007

Prepared for the 


\section{Department of Energy \\ Washington, DC 20585 \\ November 20,2007}

\section{MEMORANDUM FOR RICHARD B. PROVENCHER \\ DEPUTY MANAGER FOR IDAHO CLEANUP PROJECT}

FROM:

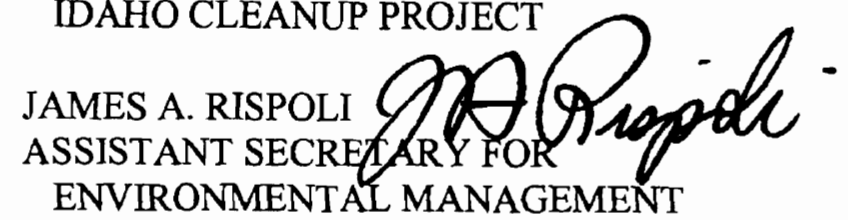

SUBJECT:

Approval of the Mission Need Statement for the Idaho Spent Fuel Facility Project at the Idaho National Laboratory Site

In accordance with the requirements of Department of Energy (DOE) Order 413.3A, Program and Project Management for the Acquisition of Capital Assets, I approve the Mission Need Statement (MNS) for the Idaho Spent Fuel Facility Project at the Idaho National Laboratory site. The original Critical Decision 0 was approved by the Office of Nuclear Energy in 1996. The approval of the Mission Need Statement is an update of the original. This MNS is approved subject to the following: DOE Order 413.3A provisions concerning incorporation of safety in planning (i.e. leading to and subsequent to $C D-1$ ) and design (i.e. leading to and subsequent to CD-2) shall be rigorously applied. Additionally Environmental Management and other DOE guidance and direction shall be likewise applied.

I expect the project director to present all remaining critical decisions to the EMAAB formally and meet the requirements of DOE Order 413.3A issued July 28,2006 . The project director should also assure accurate and current information is being reported in the Integrated Planning, Accountability, and Budgeting System, and keep Headquarters informed on progress and potential problems that may impact the project and Settlement Agreement milestones.

If you have any further questions, please contact me at (202) 586-7709 or Mr. Mark W. Frei, Deputy Assistant Secretary for Program Planning and Budget, at (202) 586-8754.

Attachment

cc:

Beth Sellers, DOE-I 
Mission Need Statement: Idaho Spent Fuel Facility Project

DOEAD-11344

September 2007

Approved by

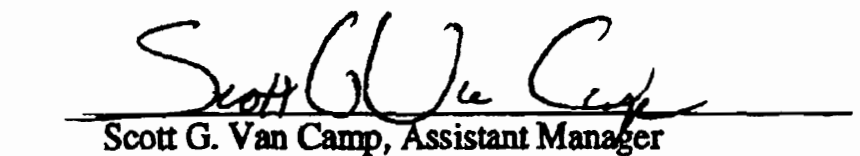

Scott G. Van Camp, Assistant Manager Facility pend Material Disposition

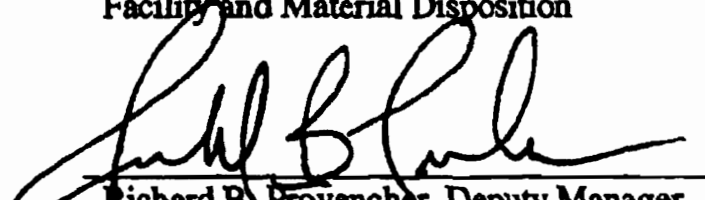

richard B! Provencher, Deputy Manager Idaho Cleanup Project

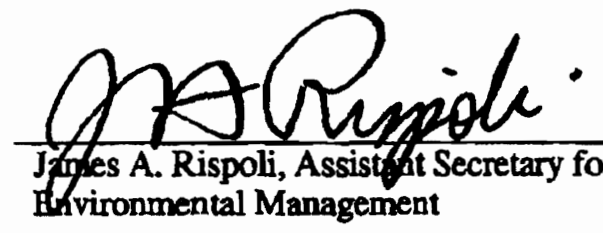

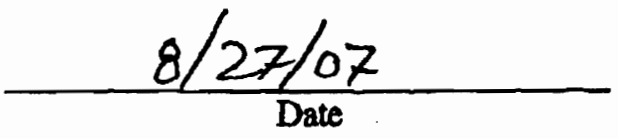

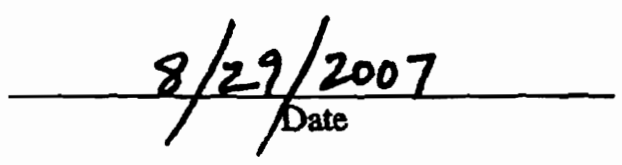

Of ov.19,2007

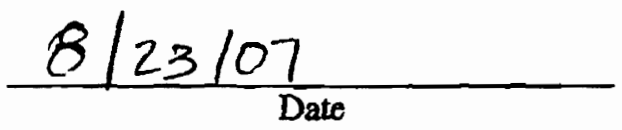

Originator: Barbara Belle

Telephone: 208-526-0235

Organization: EM/ICP/Materials Disposition

Project 


\section{Mission Need Statement: Idaho Spent Fuel Facility Project}

September 2007

Prepared by the U.S. Department of Energy DOE Idaho Operations Office 


\begin{abstract}
Approval is requested based on the information in this Mission Need Statement for The Department of Energy, Idaho Operations Office (DOE-ID) to develop a project in support of the mission established by the Office of Environmental Management to "complete the safe cleanup of the environmental legacy brought about from five decades of nuclear weapons development and government-sponsored nuclear energy research". DOE-ID requests approval to develop the Idaho Spent Fuel Facility Project that is required to implement the Department of Energy's decision for final disposition of spent nuclear fuel in the Geologic Repository at Yucca Mountain. The capability that is required to prepare Spent Nuclear Fuel for transportation and disposal outside the State of Idaho includes characterization, conditioning, packaging, onsite interim storage, and shipping cask loading to complete shipments by January 1,2035 . These capabilities do not currently exist in Idaho.
\end{abstract}




\section{EXECUTIVE SUMMARY}

Since its establishment in 1949, the Idaho National Laboratory Site (INL) has fulfilled numerous Department of Energy (DOE) missions including designing and testing of 52 nuclear reactors and reprocessing spent nuclear fuel to recover fissile materials. The laboratory is responsible for storing and dispositioning approximately 285-300 metric tons of spent nuclear fuel (SNF) from a number of sources, including the Navy, foreign and domestic research reactors, and commercial reactors, along with DOE owned fuel.

In the past, the wide variety of spent nuclear fuel types and conditions were destined for reprocessing to recover fissile materials. Due to the reduced need for special nuclear materials, DOE initiated the phase out of reprocessing in April 1992. Consequences of this phase out are the increasing inventory of SNF in aging facilities and the need to store the nuclear fuel much longer than previously envisioned.

Increasing concern that Idaho was becoming a permanent repository for SNF prompted the State of Idaho to initiate litigation in 1992. As a result of this litigation, the Federal District Court for the District of Idaho ruled, in June 1993 that DOE was required to prepare an Environmental Impact Statement (EIS) for continued receipt of SNF at the INEL (sic.) This issue and subsequent disputes culminated in the October 16, 1995 Joint Motion for Entry of Consent Order Based on Settlement Agreement with the State of Idaho, DOE, and the United States Navy that resolved the litigation. The Idaho Settlement Agreement (SA) requires that DOE complete shipment of all SNF from Idaho by January 1, 2035. The consequence of missing a SA milestone is the suspension of DOE spent fuel shipments into Idaho. This Mission Need Statement (MNS) identifies the need to establish the Idaho Spent Fuel Facility (ISFF) Project to prepare fuel for transfer out of aging facilities in Idaho and disposal in the geologic repository.

The DOE Environmental Management (EM) Program is responsible for managing the variety of radioactive and hazardous wastes that originate from past missions by treating, storing and disposing of a variety of waste streams, cleaning up the environment, removing or deactivating unneeded facilities, and will remove DOE's inventory of spent nuclear fuel and high-level waste from Idaho in compliance with the SA. The Idaho Cleanup Project (ICP) is an element of the DOE Office of EM.

DOE-ID requests approval to develop the ISFF Project that is required to implement the DOE's decision for final disposition of spent nuclear fuel in the Geologic Repository at Yucca Mountain. The capability that is required to prepare spent nuclear fuel (SNF) for transportation and disposal outside the State of Idaho includes characterization, conditioning, packaging, onsite interim storage, and shipping cask loading to complete shipments by January 1, 2035. These capabilities do not currently exist in Idaho.

The ISFF Project would be a subproject of the ICP with responsibility to prepare all EMowned SNF stored at the Idaho Nuclear Technology and Engineering Center (INTEC) for transport out of Idaho. INTEC was built in the 1950s to reprocess spent nuclear fuel to recover uranium. The majority of fuel storage facilities were constructed in the early 1970 for storage of specific fuel types staged for reprocessing. Fuel storage capabilities have been expanded through 
changes to the Documented Safety Analysis for each facility through the years. The aging SNF facilities are nearing or at their storage capacity and design life and do not have capability for fuel characterization, conditioning, packaging, interim storage of packaged fuel and loading of the transportation system for shipment to the repository. Approval of the ISFF Project MNS is requested to allow development of a project to:

- Meet legal commitments made by DOE in the SA.

- Implement the 1995 Idaho EIS Record of Decision (ROD).

- Avoid potential impact to anticipated spent nuclear fuel swaps between the Savannah River Site (SRS) and INL necessary to complete the Enriched Uranium Disposition Project as currently planned.

- Reduce environmental risks of continued storage of nuclear fuel over the Snake River Plain Aquifer.

This project will allow DOE to implement the decisions recorded in the following documents:

- The June 1, 1995, Environmental Impact Statement Record of Decision for the DOE Programmatic Spent Nuclear Fuel Management and INEL Environmental Restoration and Waste Management Programs Final Environmental Impact Statement

- The 2006 DOE Strategic Plan, Strategic Theme 4, Goal 4.1, by providing the capability at the INL to "Ensure safe and secure management of nuclear materials and radioactive wastes and enable final disposition of these materials in a geologic repository."

- Department of Energy Five Year Plan FY 2008 - FY 2012 for Environmental Management issues February 2007 by Office of the Chief Financial Officer

If the ISFF Project is not approved and the SNF subsequently retrieved, characterized, conditioned, packaged, and readied for onsite interim storage or shipment out of Idaho, consequences could include the following:

- DOE SNF shipments into Idaho will be suspended. (The SA states in Section K.1.a. "If DOE fails to satisfy the substantive obligations or requirements it has agreed to in this Agreement or fails to meet deadlines for satisfying such substantive obligations or requirements, shipments of DOE spent fuel to INEL shall be suspended unless and until the parties agree or the Court determines that such substantive obligations or requirements have been satisfied.").

- Suspension of fuel shipments into Idaho could impact the anticipated spent nuclear fuel swaps planned between the SRS and INL between FY 2008 and FY 2016, as addressed in the Enriched Uranium Disposition Project. Critical Decisions (CD-0 and CD-1) were approved for the Enriched Uranium Disposition Project in 2006. 
- Stakeholders, including state and federal administrative bodies, will lose confidence in DOE's ability to meet legally binding commitments.

- DOE's goals of accelerating cleanup, reducing environmental risk and reducing clean-up costs would not be achieved.

The repository license application has been delayed and that delay contributes to disposal uncertainty. The ISFF Project would leverage past work while maintaining project flexibility despite repository licensing uncertainty and meets DOE's SA commitments. 


\section{CONTENTS}

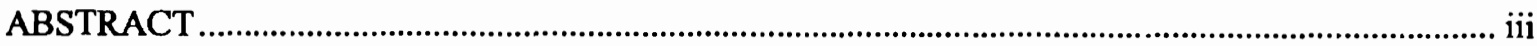

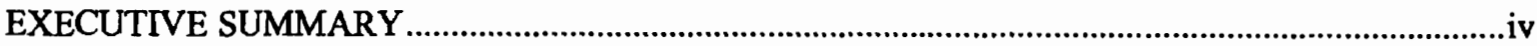

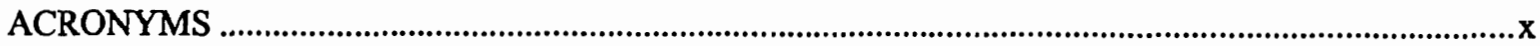

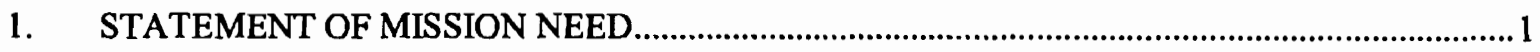

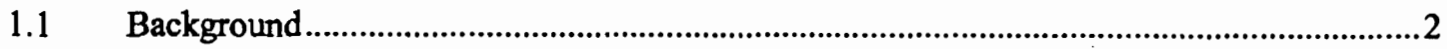

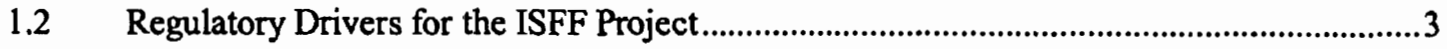

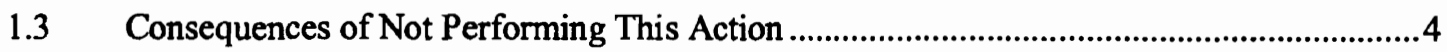

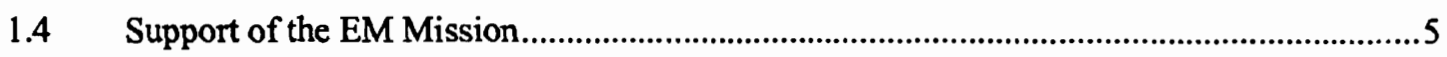

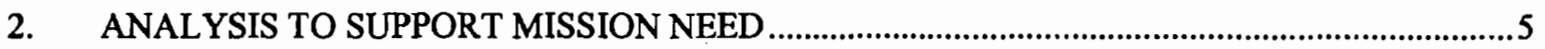

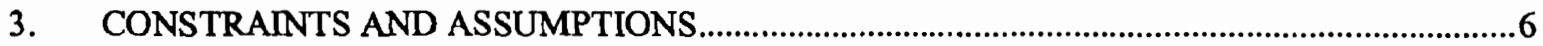

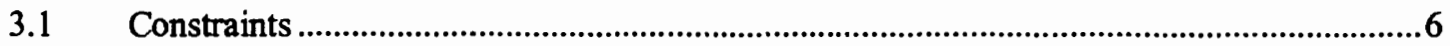

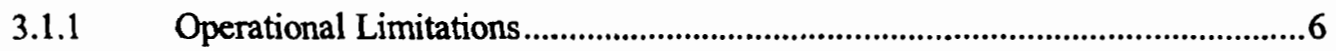

3.1.2 Limitations Associated with the Geographical Location.....................................

3.1.3 Standardization and Standards Requirements ...................................................

3.1.4 Environmental, Safety and Health Requirements............................................

3.1.5 Safeguards and Security Considerations ..........................................................8

3.1.6 Interfaces with Existing and Planned Acquisitions .............................................8

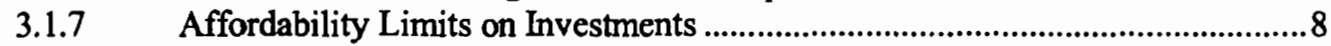

3.1.8 Legal and Regulatory Constraints and Requirements ....................................... 8

$3.2 \quad$ Assumptions ................................................................................................................

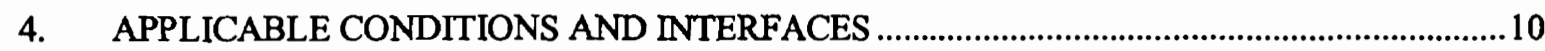

4.1 Compatibility Requirements with Existing or Future Systems........................................ 10

4.2 Integration with Similar Department Needs ....................................................................... 10

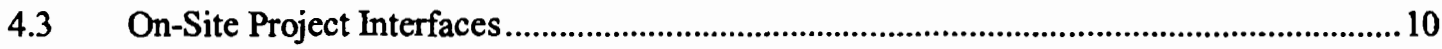

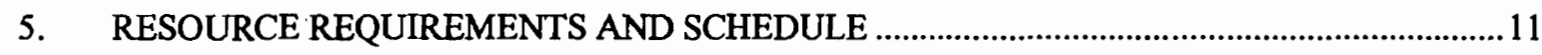

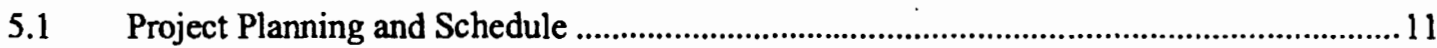

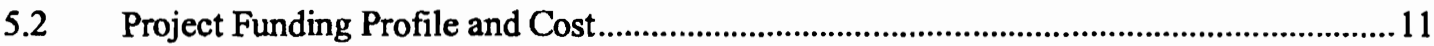

5.3 Measures to Determine Project Success ........................................................................... 12

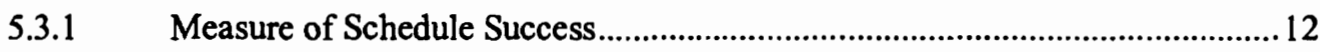

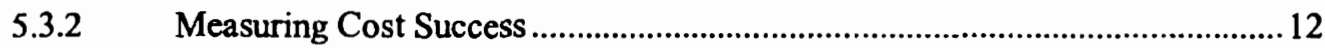


5.3.3 Measuring Successful Project Completion .........................................................13

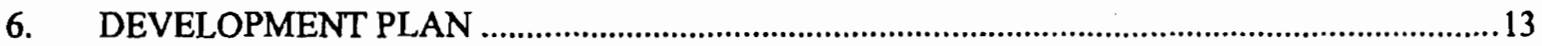

6.1 Previous Planning Activities........................................................................................... 13

6.2 Schedule for Reaching the Major Milestones and Critical Decision Points ..........................13

6.3 Approach to Concept Development.................................................................................

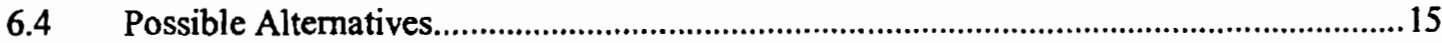


This page is intentionally left blank. 


\section{ACRONYMS}

\begin{tabular}{|c|c|}
\hline ALARA & As Low as Reasonably Achievable \\
\hline $\mathrm{CD}$ & Critical Decision \\
\hline CERCLA & Comprehensive Environmental Response, Compensation, and Liability Act \\
\hline CFR & Code of Federal Regulations \\
\hline $\mathrm{D} \& \mathrm{D}$ & decontamination and decommissioning \\
\hline DRR & Domestic Research Reactor \\
\hline DOE & U.S. Department of Energy \\
\hline EIS & environmental impact statement \\
\hline EM & Environmental Management \\
\hline EPA & Environmental Protection Agency \\
\hline FRR & Foreign Research Reactor \\
\hline ICP & Idaho Cleanup Project \\
\hline $\mathrm{INL}$ & Idaho National Laboratory \\
\hline INTEC & Idaho Nuclear Technology and Engineering Center \\
\hline ISFF & Idaho Spent Fuel Facility \\
\hline ISFSI & Independent Spent Fuel Storage Installation \\
\hline ISMS & Integrated Safety Management System \\
\hline MTHM & metric tons heavy metal \\
\hline MNS & Mission Need Statement \\
\hline NSNFP & National Spent Nuclear Fuel Program \\
\hline NRC & U.S. Nuclear Regulatory Commission \\
\hline OCRWM (RW) & Office of Civilian Radioactive Waste Management \\
\hline OSHA & Occupational Safety and Health Administration \\
\hline PDSA & preliminary documented safety analysis \\
\hline PED & Project Engineering and Design \\
\hline
\end{tabular}


ROD

SA

SNF

SRS

VPP

WASRD record of decision

settlement agreement

spent nuclear fuel

Savannah River Site

Voluntary Protection Program

Waste Acceptance System Requirements Document 
This page is intentionally left blank. 


\section{Mission Need Statement Idaho Spent Fuel Facility Project}

\section{STATEMENT OF MISSION NEED}

The mission of the ISFF Project is to provide the capability to prepare approximately $285-300$ Metric Tons Heavy Metal (MTHM) of SNF currently owned by the DOE and stored in aging facilities at the INTEC on the INL Site for shipment out of Idaho and ultimate disposal in the geologic repository at Yucca Mountain. SNF is the largest source of radioactivity at the INL Site. The ISFF Project mission supports the DOE's 2006 Strategic Plan, Strategic Theme 4, Goal 4.1 , by providing the capability at the INL to "Ensure safe and secure management of nuclear materials and radioactive wastes and enable final disposition of these materials in a geologic repository." The project will provide safe and efficient characterization, conditioning and packaging capability to place SNF in a configuration suitable for shipment out of Idaho for disposal in the Geologic Repository (repository) by January 1, 2035. Disposition of SNF at a repository will result in reduction in risk to the environment by removing SNF storage over the Snake River Plain Aquifer and fuel from aging facilities plagued with reliability and maintainability problems.

DOE has a legal obligation, established by the Settlement Agreement (SA) between the State of Idaho, the DOE, and the Department of the Navy, to resolve all issues in the actions Public Service Co. of Colorado v. Batt, No. CV-91-0035-S-EJL (D. Id.) and United States v. Batt, No. CV-91-0065-S-EJL (D. Id.), dated October 16, 1995, to have all SNF out of Idaho by December 31, 2035. The Idaho SA also established interim milestones for SNF. SNF milestones to date have been accomplished on time. There are two remaining milestones associated with SNF; December 31, 2023 complete transfer of all spent fuel from wet storage facilities and January 1, 2035 remove all spent fuel, including Naval spent fuel and Three Mile Island spent fuel from Idaho. There is currently adequate dry storage capacity to move all DOE EM-owned fuel from wet to dry storage to meet the 2023 date. The capability to characterize, condition and package SNF for shipment out of Idaho is required.

Characterization and conditioning as defined in the Memorandum of Agreement for Acceptance of Spent Nuclear Fuel and High Level Radioactive Waste between the Assistant Secretary for Environmental Management and the Director, Office of Civilian Radioactive Waste Management includes the following:

- Characterization - Performance of the activities (e.g., data collection, testing, inspection, document preparation, analyses) necessary to describe SNF and HLW adequately for acceptance, transportation and disposal (this includes preclosure and post closure performance in the repository).

- Conditioning - any process which prepares or treats SNF or HLW for transportation or disposal in accordance with regulatory requirements and RW acceptance criteria. This includes processing (e.g. vitrification) of HLW and passiviation of SNF. 
Between 1997 and 2004, all legacy SNF at the INL site was consolidated at INTEC. In addition, ICP is responsible for the SNF stored in the Nuclear Regulatory Commission (NRC) licensed Fort St. Vrain Independent Spent Fuel Storage Installation (ISFSI) located at Platteville, Colorado. The SNF in this facility is from the Fort St. Vrain commercial power reactor.

Approximately $1 / 3$ of the core from this reactor is stored at INTEC, and the balance remains in Colorado. In accordance with separate formal agreements with the DOE, Idaho and Colorado, the Fort St. Vrain fuel cannot be stored in Idaho but may be brought to the state for repackaging after a permanent repository or interim storage facility outside Idaho is open and receiving shipments from the INL.

EM-owned fuel will continue to be moved from basin to dry storage. Completion of the "wet to dry" fuel transfers for EM-owned fuel is scheduled in 2009. Although the fuel packages will be moved to dry storage facilities by 2009 , the fuel within canisters may contain residual water or are flooded. Fuel must be conditioned i.e., packaged in a DOE standardized canister, dried, to meet transportation and repository acceptance criteria, poisoned (when required), seal welded and backfilled with inert gas. The capability for drying, and packaging SNF in DOE SNF canisters does not exist.

The throughput rate for fuel characterization and conditioning is currently dependent on the rate that fuel can be retrieved from existing storage facilities and moved/shipped to the new capability. Studies indicate that the schedule required to prepare and ship fuel out of the state is beyond the 2035 SA milestone date, assuming availability of the ISFF capability in the 2019

timeframe. Optimization of the schedule through time and motion studies will be pursued if this project is supported.

\subsection{Background}

From 1952 to 1992, DOE and its predecessor agencies reprocessed spent nuclear reactor fuel at the Idaho Chemical Processing Plant located on the Snake River Plain in southeast Idaho. This facility, now known as the INTEC, is part of the INL Site. Processing operations at INTEC utilized multiple cycles of solvent extraction to recover uranium-235 and other defense-related materials from spent nuclear reactor fuel. The wide variety of SNF types and conditions currently stored at the INL was destined for reprocessing to recover fissile materials. Due to the reduced need for special nuclear materials, DOE initiated the phase out of reprocessing in 1992. Consequences of this phase out are the increasing inventory of SNF in aging facilities and the need to store SNF much longer than previously envisioned.

Increasing concern that Idaho was becoming a permanent repository for SNF prompted the State of Idaho to initiate litigation in 1992. As a result of this litigation, the Federal District Court for the District of Idaho ruled, in June 1993 that DOE was required to prepare an Environmental Impact Statement (EIS) for continued receipt of SNF at the INEL (sic). This issue and subsequent disputes culminated in the October 16, 1995 Joint Motion for Entry of Consent Order Based on Settlement Agreement with the State of Idaho, DOE, and the United States Navy that resolved the litigation. The Idaho SA requires that DOE complete shipment of all SNF from Idaho by January 1, 2035. The consequence of missing a SA milestone is the suspension of DOE spent fuel shipments into Idaho. This MNS identifies the need to establish 
the ISFF Project to determine and implement method to be used to accomplish SNF shipment to a geologic repository.

In 1982, the U.S. Congress enacted the Nuclear Waste Policy Act. The Act established a comprehensive national program for the safe, permanent disposal of highly radioactive wastes and directed the U.S. Department of Energy to study suitable sites for a geologic repository. The repository envisioned by the Act is an engineered disposal facility located deep underground. After more than two decades of scientific study, in 2002, Congress and the President approved the development of a repository at Yucca Mountain, Nevada. Following the discontinuation of reprocessing the disposition path for most DOE SNF is disposal at the repository. This project will prepare SNF for the planned disposition path, disposal in the repository at Yucca Mountain, and will provide storage until the fuel is shipped out of Idaho.

\subsection{Regulatory Drivers for the ISFF Project}

The ISFF project regulatory driver is the October 16, 1995 Joint Motion for Entry of Consent Order Based on the SA that resolved the litigation. The Idaho SA requires that DOE complete shipment of all SNF from Idaho by January 1,2035. Following is a list of the SA milestones pertaining to SNF:

List of current SNF Regulatory Milestones

\begin{tabular}{|c|c|c|}
\hline Idaho Settlement Agreement Milestone Description & $\begin{array}{c}\text { Milestone } \\
\text { Date }\end{array}$ & Status \\
\hline $\begin{array}{l}\text { C. } 1 \text { DOE shall remove all spent fuel, including naval spent fuel } \\
\text { and Three Mile Island spent fuel form Idaho by January } 1,2035 \text {. } \\
\text { Spent fuel being maintained for purposes of testing shall be } \\
\text { exempted from removal, subject to the limitations of section F.1 of } \\
\text { this agreement. }\end{array}$ & $1 / 1 / 2035$ & $\begin{array}{l}\text { The ISFF project is required to } \\
\text { complete this requirement. }\end{array}$ \\
\hline $\begin{array}{l}\text { E.8 Transfer Out of Wet Storage. By December } 31,1999, \mathrm{DOE} \\
\text { shall commence negotiating a schedule with the State of Idaho for } \\
\text { the transfer of all spent fuel at INEL out of wet storage facilities. }\end{array}$ & $12 / 31 / 99$ & Complete. \\
\hline $\begin{array}{l}\text { E. } 8 \text { Transfer Out of Wet Storage. DOE shall complete the transfer } \\
\text { of all spent fuel from wet storage facilities at INEL be December } \\
31,2023 \text {. }\end{array}$ & $12 / 31 / 23$ & $\begin{array}{l}\text { Following discontinuation of } \\
\text { reprocessing in the } 1992 \text {, } \\
\text { evaluations showed that new } \\
\text { dry storage was required to } \\
\text { complete the wet to dry } \\
\text { transfers. Since that time, fuel } \\
\text { receipt schedules have changed, } \\
\text { seismic vulnerabilities were } \\
\text { corrected at an existing dry } \\
\text { storage facility, and changes to } \\
\text { the safety basis allows larger } \\
\text { quantities and types of fuel to } \\
\text { be stored in existing facilities. } \\
\text { Wet to dry transfer for EM- } \\
\text { owned fuel is projected to } \\
\text { complete } 9 / 30 / 09 \text {. }\end{array}$ \\
\hline $\begin{array}{l}\text { F.1 Establishment of INEL as DOE Spent Fuel Lead Laboratory. } \\
\text { DOE shall, within thirty days of entry of this Agreement as a court } \\
\text { order, designate INEL as the Department's lead laboratory for } \\
\text { spent fuel. DOE shall direct research, development and testing of }\end{array}$ & $11 / 15 / 95$ & $\begin{array}{l}\text { Complete } \\
\text { National Spent Nuclear Fuel } \\
\text { Program is established and is } \\
\text { the EM interface with RW to }\end{array}$ \\
\hline
\end{tabular}




\begin{tabular}{|c|c|c|}
\hline Idaho Settlement Agreement Milestone Description & $\begin{array}{l}\text { Milestone } \\
\text { Date }\end{array}$ & Status \\
\hline $\begin{array}{l}\text { treatment, shipment and disposal technologies for all DOE spent } \\
\text { fuel, and all such DOE activities shall be coordinated and } \\
\text { integrated under the direction of the Manager, DOE-Idaho } \\
\text { Operations Office. Such designation shall not permit the shipment } \\
\text { to INEL of any spent fuel beyond that permitted by this } \\
\text { Agreement with the exception that quantities of spent fuel brought } \\
\text { to INEL for testing in excess of those permitted by this Agreement } \\
\text { shall leave the State of Idaho within five years of the date of } \\
\text { receipt at INEL. }\end{array}$ & 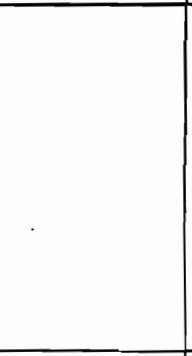 & $\begin{array}{l}\text { ensure EM fuel is included in } \\
\text { the NRC license application. }\end{array}$ \\
\hline $\begin{array}{l}\text { F. } 2 \text { Construction of Dry Storage. DOE shall include in its } \\
\text { appropriation request for federal fiscal year } 1998 \text { to the Executive } \\
\text { Office of the President funds necessary for DOE to initiate the } \\
\text { procurement of dry storage at INEL to replace wet, below ground } \\
\text { facilities. }\end{array}$ & 1996-1998 & $\begin{array}{l}\text { Appropriation requested in } \\
1996 \text { and in } 1998 \text {. Contract } \\
\text { awarded in } 2000 \text { and } \\
\text { terminated in } 2006 \text { following } \\
\text { completion of NRC licensing } \\
\text { and design. Unobligated } \\
\text { funding was deobligated from } \\
\text { Idaho for higher EM priorities } \\
\text { in July } 2006 \text {. Fuel is being } \\
\text { transferred to existing dry } \\
\text { storage but has not been } \\
\text { prepared for transfer out of } \\
\text { state which falls short of the } \\
\text { intent of this requirement. } \\
\text { Approval of this MNS would } \\
\text { show progress toward fuel } \\
\text { disposition, i.e. transfer out of } \\
\text { Idaho. }\end{array}$ \\
\hline $\begin{array}{l}\text { F.2 Construction of Dry Storage. Spent fuel loading into dry } \\
\text { storage shall commence by July } 1,2003 \text {. }\end{array}$ & $7 / 1 / 03$ & $\begin{array}{l}\text { Accomplished by transferring } \\
\text { fuel from a canal to existing dry } \\
\text { storage. }\end{array}$ \\
\hline $\begin{array}{l}\text { F.4 Multi-Purpose Canisters. DOE and the Navy shall employ } \\
\text { Multi-Purpose Canisters ("MPCs") or comparable systems to } \\
\text { prepare spent fuel located at INEL for shipment and ultimate } \\
\text { disposal of such fuel outside Idaho. Procurement shall be } \\
\text { performed in accordance with the Federal Acquisition Regulation } \\
\text { which ensures that companies in Idaho will have opportunity to } \\
\text { bid on and obtain any competitive contracts for such work. The } \\
\text { Record of Decision on the NEPA analysis shall be completed by } \\
\text { April 30, } 1999 \text {. }\end{array}$ & $4 / 30 / 99$ & $\begin{array}{l}\text { Complete. } \\
\text { DOE Standardized Canisters } \\
\text { are the key component of the } \\
\text { "comparable system". }\end{array}$ \\
\hline
\end{tabular}

\subsection{Consequences of Not Performing This Action}

If the SNF is not prepared for shipment out of Idaho on the schedule presented in this MNS, consequences include the following:

- DOE SNF shipments into Idaho may be suspended. (The Settlement Agreement states in Section K.1.a. "If DOE fails to satisfy the substantive obligations or requirements it has agreed to in this Agreement or fails to meet deadlines for satisfying such substantive obligations or requirements, shipments of DOE spent fuel to INEL shall be suspended 
unless and until the parties agree or the Court determines that such substantive obligations or requirements have been satisfied.").

- Stakeholders, including state and federal administrative bodies, will lose confidence in DOE's ability to meet legally binding commitments.

- Suspension of fuel shipments into Idaho could impact the anticipated SNF swaps planned between the SRS and INL between FY 2008 and FY 2016, as addressed in the Enriched Uranium Disposition Project [Critical Decisions (CD)-0 and 1 approved in 2006].

- Fuel will continue to be stored in aging facilities with increasing maintenance costs.

Initiation of the ISFF Project could mitigate the consequences above and enables DOE to proceed toward meeting its legal obligations despite the schedule uncertainty surrounding the repository licensing process.

\subsection{Support of the EM Mission}

The ISFF supports the 2006 DOE Strategic Plan, Strategic Theme 4, Goal 4.1, Environmental Cleanup by providing the capability at the INL to "Ensure safe and secure management of nuclear materials and radioactive wastes and enable final disposition of these materials in a geologic repository." The project will provide safe and efficient characterization and conditioning capability to place SNF in a configuration suitable for shipment out of Idaho for disposal in the repository.

\section{ANALYSIS TO SUPPORT MISSION NEED}

Following termination of reprocessing of spent nuclear fuel in 1992, numerous options for storage and disposition of SNF were evaluated. In April 1995, DOE completed the DOE Programmatic Spent Nuclear Fuel Management and Idaho National Engineering Laboratory Environmental Restoration and Waste Management Programs Environmental Impact Statement (SNF \& INEL EIS). The programmatic EIS analyzed the no action alternative i.e., safe and secure management of SNF at or near the point of generation, and alternatives for SNF management within the DOE complex. The June 1 1995, Environmental Impact Statement Record of Decision for the DOE Programmatic Spent Nuclear Fuel Management and INEL Environmental Restoration and Waste Management Programs Final Environmental Impact Statement establishes the SNF management strategy to regionalize SNF management by fuel type. The INL site is responsible for managing and receiving non-aluminum clad fuels, including Naval SNF and SNF from other DOE facilities. The INL site also receives SNF from domestic and foreign research reactors to support non-proliferation and national security objectives. Following is a list of project related NEPA documents that reference pertinent analyses:

- March 1999 per paragraph F.4 of the Settlement Agreement, DOE-ID issued DOE/ID10636, Supplement Analysis for a Container System for the Management of DOE Spent Nuclear Fuel Located at the INEEL. 
- May 4, 1999 - Federal Register Notice ROD for a Multi-Purpose Canister or Comparable System for Idaho National Engineering and Environmental Laboratory Spent Nuclear Fuel.

- February 24, 2004 - NUREG 1773, Environmental Impact Statement for the Proposed Idaho Spent Fuel Facility at the Idaho National Engineering and Environmental Laboratory in Butte County Idaho Final Report.

In the mid 1990s the National Spent Nuclear Fuel Program (NSNFP) was established to provide technology and guidance needed for safe, efficient handling and disposition of DOE SNF to:

- Ensure that all needed DOE SNF analyses and information are in the Yucca Mountain License Application

- Meet regulatory and programmatic requirements associated with disposal at the repository.

- Establish repository acceptance criteria in cooperation with Office of Civilian Radioactive Waste Management (RW) and DOE sites.

The NSNFP has completed extensive research and documentation of DOE-owned fuel. Due to the variety of fuel types and physical condition of fuel managed by DOE, the NSNFP developed the DOE standardized canisters for handling and interim storage of SNF at various DOE sites as well as SNF transport to, handling, and disposal at the repository. The Draft NRC license application for the repository identifies standardized canisters as the configuration for receipt of INL SNF.

The SNF will be disposed at the repository according to the requirements of the Nuclear Waste Policy Act, Waste Acceptance System Requirements Document, prepared by RW and the Memorandum of Agreement for Acceptance of Spent Nuclear Fuel and High-Level Radioactive Waste. Feasibility Studies have been conducted since 1993 to develop a project to put DOE SNF in a compliant condition for disposal at the repository.

\section{CONSTRAINTS AND ASSUMPTIONS}

\subsection{Constraints}

\subsubsection{Operational Limitations}

The throughput capability of the ISFF is dependent on the ability to retrieve fuel from existing onsite storage locations, the drying time required for the wide range of fuel types and the repository opening date. Interim storage of packaged SNF pending disposal at the repository is included in the ISFF preliminary planning estimate. The intent is to reduce the need for interim storage and optimize "just-in-time" shipping if the repository is available for SNF receipt. 
SNF requires special operating methods to shield personnel from radiation, in accordance with as low as reasonably achievable (ALARA) principles. SNF conditioning, characterization, packaging, loading, onsite interim storage, and transportation capabilities will require specific remote operations and remote maintenance.

\subsubsection{Limitations Associated with the Geographical Location}

The June 1, 1995, Environmental Impact Statement Record of Decision for the DOE Programmatic Spent Nuclear Fuel Management and INEL Environmental Restoration and Waste Management Programs Final Environmental Impact Statement establishes an SNF management strategy to regionalize SNF management by fuel type. The INL site is responsible for managing and receiving non-aluminum clad fuels, including Naval SNF and SNF from other DOE facilities. The $\mathbb{N} L$ site also receives Domestic Research Reactor Fuel (DRR) and Foreign Research Reactor Fuel (FRR) to support non-proliferation and national security objectives.

The Record of Decision also states "Spent fuels currently stored at various locations at the Idaho National Engineering and Environmental Laboratory will be consolidated at the Idaho Chemical Processing Plant facilities as funding allows." The Idaho Chemical Processing Plant was renamed and is now INTEC. The proposed capability for characterization and conditioning of fuel should be located at INTEC near the current SNF storage facilities.

\subsubsection{Standardization and Standards Requirements}

The capability to characterize, condition and package SNF will be constructed within industry standards. Facilities will be constructed to meet local, state, and national codes, such as the International Building Code and National Electrical Code. The facility will also be built to meet the INL Site seismic requirements. SNF facilities, operations, and equipment important to waste acceptance at the repository and product quality will meet the Quality Assurance Requirements and Description (DOE/RW-0333P).

\subsubsection{Environmental, Safety and Health Requirements}

The SA was crafted to reduce the risk of radioactive contamination release to the Snake River Plain Aquifer. The aquifer underlies the entire INL site and is an Environmental Protection Agency (EPA) designated sole-source aquifer, which provides water for farming, industry, and domestic uses for much of southern Idaho. Transfer of EM-owned SNF out of Idaho by January 1, 2035 will mitigate this risk.

During construction, applicable regulations such as Occupational Safety and Health Administration (OSHA) and INL Site construction safety practices will be met. No unusual construction methods or practices are anticipated. During operation, the facility will adhere to safety practices such as the Integrated Safety Management System (ISMS) and Voluntary Protection Program (VPP). Facility regulatory requirements pertaining to storage of commercial SNF will be met to ensure protection of human health and environment.

Under the INL Site's ISMS, a project safety and health representative will be assigned to the Integrated Project Team and will support the project manager in implementing the project safety and health program. The project will comply with DOE orders and INL Site 
requirements. DOE orders defining environmental related requirements include DOE Order 5400.1, General Environmental Protection Program, and DOE Order 5400.5, Radiation Protection of the Public and the Environment. The Radiological Control Program will comply with requirements of 10 Code of Federal Regulations (CFR) 835 and DOE Order 441.1 series. The project will incorporate the radiological control requirements and procedures into the project documents and these will flow down to subcontractors during design and construction.

The regulatory authority for DOE-owned and commercial fuel will be determined as the project progresses through the critical decision process. The NRC regulatory requirements are defined in 10 CFR Part 72. If the facility is regulated by DOE, a Preliminary Documented Safety Analysis (PDSA) report will be completed per DOE STD-3009-94 and DOE Order 420. Quality levels will be established. Safety Categories will be established and used as the basis for applying the graded approach criteria required in 10 CFR 830, Subpart A, and in DOE Order 414.1A. Criticality will be addressed in the PDSA.

\subsubsection{Safeguards and Security Considerations}

Safeguards and security considerations will be integrated in the design and operation of ISFF facilities as dictated by threat basis evaluations.

\subsubsection{Interfaces with Existing and Planned Acquisitions}

Selection of an alternative to provide the required capabilities, timing for the project and acquisition strategy will likely be required to support development of the scope

The Office of Civilian Radioactive Waste Management (RW) is responsible for procurement of the shipping package and transportation system to ship SNF from DOE sites to the repository. The NSNFP is the interface with RW, tracking decisions made through the development, design and acquisition of the DOE SNF shipping packages which is important for project success.

\subsubsection{Affordability Limits on Investments}

Establishing the ISFF Project's technical strategy includes evaluating alternatives. The characterization, conditioning and packaging capability will be designed to minimize operating and life-cycle costs, while providing the required functions.

\subsubsection{Legal and Regulatory Constraints and Requirements}

This project is a DOE Environmental Management activity at the INL Site and is subject to laws and regulations that apply to the treatment, storage, and disposal of wastes. Legal, federal, and state requirements for the management of at INTEC include those established under the following: 
Atomic Energy Act

Nuclear Waste Policy Act

Idaho Settlement Agreement

Clean Air Act

Clean Water Act
The Atomic Energy Act of 1954 (42 USC 2011 et seq.) establishes responsibility for the regulatory control of radioactive materials including radioactive wastes. Pursuant to the Atomic Energy Act, DOE established a series of standards (DOE orders) to protect health and minimize danger to life or property from activities at its facilities.

The Nuclear Waste Policy Act of 1982, as amended (42 USC 10101 et seq.), established a national policy for disposal of civilian HLW and spent nuclear fuel in a geologic repository.

In October 1995, the State of Idaho, Department of the Navy, and DOE settled the cases of Public Service Company of Colorado v. Batt, involving the management of spent nuclear fuel at INL Site. The Settlement Agreement/Consent Order (USDC 1995) requires DOE to:

- Complete transfer of all SNF from the state of Idaho by January 1, 2035.

Design, construction and operations will be regulated under the Clean Air Act.

If applicable, Storm Water requirements will be met.

\subsection{Assumptions}

ISFF Project assumptions include the following:

- Funding will be available beginning in FY09 (\$2M).

- Project Engineering and Design (PED) funding available in 2013.

- All fuel will be packaged in DOE standardized canisters.

- The moderator exclusion exemption for seal welded DOE standardized canisters during transportation will be granted by the NRC.

- Pretreatment of fuel i.e. sodium bonded and epoxy coated fuel will be performed prior to receipt at this facility, outside the scope of this project.

- DOE will submit the NRC license application for the repository at Yucca Mountain in June 2008.

- The application will be accepted for technical review by the NRC.

- The repository will begin to receive SNF in 2017.

- DOE-ID will begin to ship fuel to the repository in 2020.

- SNF shipping costs for SNF are borne by RW. 
- Costs for development and fabrication of the shipping casks will be borne by RW.

- SNF repository disposal costs are not included in the project i.e. payment to the Nuclear Waste Fund.

- Deactivation, closure and demolition of ISFF Project facilities will include clean closure of new facilities and performance-based closure for existing facilities.

\section{APPLICABLE CONDITIONS AND INTERFACES}

\subsection{Compatibility Requirements with Existing or Future Systems}

The ISFF capability must interface with existing INL fuel shipping or transfer capabilities, existing storage containers, future shipping package and transportation system provided by RW and facilities and systems at the repository.

An acquisition strategy to determine the most cost-effective approach for obtaining design, procurement, construction, and startup services that comply with the project schedule will be developed. The acquisition strategy will address alternatives.

\subsection{Integration with Similar Department Needs}

In the mid 1990s the NSNFP was established to provide technology and guidance needed for safe, efficient handling and disposition of DOE SNF to:

- Ensure that all needed DOE SNF analyses and information are in the Yucca Mountain License Application

- Meet regulatory and programmatic requirements associated with disposal at the repository.

- Establish repository acceptance criteria in cooperation with RW and DOE sites.

The NSNFP coordinates EM review and comment on the Draft NRC license application documents and draft facility design basis documents for the repository to ensure that the configuration is acceptable for receipt of DOE-owned SNF.

The INL Site participates in weekly SNF complex-wide phone calls. The NSNFP also participates on these calls and chairs a semi-annually meeting to report progress toward disposal of SNF at the repository, SNF program progress at each site and is used to benchmark and share information with other DOE sites. The NSNFP accepts actions from these meetings to solve systemic SNF issues that could impact fuel shipment to and acceptance at the repository for disposal.

\subsection{On-Site Project Interfaces}

The ISFF Project is one of several subprojects that will be initiated in the post-2012 timeframe by the DOE ICP and is required to complete the EM cleanup mission in Idaho. The related projects include Decontamination and Decommission (D\&D) of existing facilities and 
Comprehensive Environmental Response, Compensation, and Liability Act (CERCLA) soils remediation. Interfaces with ongoing operations and major projects such as Calcine Disposition Project will place demands on INTEC infrastructure (electrical power, steam, water, etc.) and are expected regardless of the ISFF option selected.

\section{RESOURCE REQUIREMENTS AND SCHEDULE}

\subsection{Project Planning and Schedule}

The requirement of the SA is to have all SNF shipped out of Idaho by January 1, 2035. Engineering feasibility studies at various levels of detail have been performed for SNF retrieval, packaging, loading, and shipping. Because the repository license application has been delayed, it is unlikely the repository will be able to receive SNF prior to 2017. The project will proceed to meet the regulatory milestone.

The table below provides the planned CD dates for the ISFF Project. The critical path is driven by funding constraints coupled with the January 1, 2035 Settlement Agreement milestone to have all fuel out of Idaho. CD-0 approval is desired in the near term to give stakeholders some assurance that DOE is making progress toward agreed upon milestones and to maintain a project that would transfer fuel from aging facilities in the event that the repository schedule is extended. Schedule estimates will continue to be developed and refined as required by DOE Order 413.3A, Program and Project Management for the Acquisition of Capital Assets, prior to subsequent critical decisions. Future schedule and project performance will be dependent upon and directly impacted by numerous external entities and actions (State of Idaho, the repository and its NRC license application and license approval, transportation, etc.).

Critical decision dates.

\begin{tabular}{|l|l|}
\hline \multicolumn{1}{|c|}{ Decision } & \multicolumn{1}{|c|}{ Date Requested } \\
\hline $\begin{array}{l}\text { CD-0, Approve Mission Need - project initiation } \\
\text { and start of Conceptual Design (request PED } \\
\text { funds) }\end{array}$ & September 2007 \\
\hline CD-1A, Approve Alternative Selection & March 2009 \\
\hline $\begin{array}{l}\text { CD-1, Approve Preliminary Baseline Range - start } \\
\text { of Preliminary Design }\end{array}$ & $\begin{array}{l}\text { Prior to April 2012 to support expenditure } \\
\text { of PED funds beginning in October 2012 } \\
\text { (FY13). }\end{array}$ \\
\hline $\begin{array}{l}\text { CD-2, Approve Performance Baseline - start of } \\
\text { Final Design }\end{array}$ & December 2015 \\
\hline CD-3, Approve Start of Construction & June 2016 \\
\hline CD-4, Approve Start of Operations & January 2019 \\
\hline
\end{tabular}

\subsection{Project Funding Profile and Cost}

Several sets of cost estimates have been developed in the past and were used to develop an estimated range of cost of $\$ 1-3$ billion for design, construction, operation of the packaging component, long-term storage through 2035 and load-out for transport to the repository. 
Decontamination and demolition is included in the cost range. The cost estimates were developed by different organizations years apart with different sets of assumptions and did not provide a valid basis for comparing alternatives. An independent life-cycle cost analysis for two possible alternatives was completed in February 2007. The Line Item Construction Project Total Project Cost range in 2008 dollars at an 85 percent confidence interval for both cost and schedule is $\$ 460 \mathrm{M}$ to $\$ 560 \mathrm{M}$. The bounding $\mathrm{D} \& \mathrm{D}$ cost for a new stand alone facility is $\$ 47$ million in the 2035 timeframe. Repository disposal charges for non-commercial fuel and DOE-owned commercial fuel for which payment has not been made to the Nuclear Waste Fund is not included in the cost estimate.

Cost estimates will continue to be developed and refined as required by DOE Order 413.3A prior to subsequent critical decisions. The actual cost baseline for the project will be refined through project initiation and finally established with CD-2 approval as specified in DOE Order 413.3A. The dates for the critical decisions are based on the Critical Path schedule below.

\subsection{Measures to Determine Project Success}

The project end date and therefore performance metrics are driven by an enforceable milestone. The project will establish interim milestones for ease in reporting e.g., major deliverables. Figure 3 is a schedule, showing relationship of this project to the NRC license application for Yucca Mountain and the timeframe in which DOE-ID will likely begin to formulate the scope for the post-2012 ICP contract and therefore would likely require an acquisition strategy decision for this project.

\subsubsection{Measure of Schedule Success}

For the project definition phase of this project, schedule success will be measured though use of a project control system that accurately reflects the project status relative to cost and schedule performance, and tracks changes to the baseline in accordance with DOE O 413.3A, Program and Project Management for the Acquisition of Capital Assets. The current site contract does not include the ISFF project development in the target cost or scope. Whether work is added to the ICP contract or a separate contract is used, both quantitative and qualitative measures will be used to establish schedule success. The project will measure schedule performance using an earned value system to measure quantifiable work accomplishments with respect to completed deliverables. Engineering and procurement deliverables (i.e., drawings, specifications, material requisitions) are planned to be tracked using progress and performance measurement tools. Variances from planned schedule performance will be reviewed and reconciled by project management with corrective action.

\subsubsection{Measuring Cost Success}

For the project definition and conceptual design portion of this project, cost success will be measured through use of a project control system that accurately reflects the project status relative to cost and schedule performance, and tracks changes to the baseline in accordance with DOE O 413.3A, Program and Project Management for the Acquisition of Capital Assets. The project will utilize a reporting system commensurate with the scope of work to manage and the 
duration of the event. The project will maintain and use a project control system that accurately reflects the project status relative to cost and schedule performance. The project personnel will track changes to the baseline in accordance with DOE O 413.3A, Program and Project Management for the Acquisition of Capital Assets. Earned Value Management is planned to be used to report variances from the baseline planned progress. Variances from planned cost performance will be reviewed and reconciled by project management, with corrective actions identified and implemented.

\subsubsection{Measuring Successful Project Completion}

The construction phase will be complete when capability in Idaho is provided to characterize, condition, place fuel in a DOE standardized canister, seal weld and store the canister filled with SNF in interim storage staged for shipment out of state to the repository. Characterization includes development of documentation to adequately describe fuel packaged in each DOE standardized canister while conditioning includes drying, addition of poison required for disposal at the repository, seal welding the standardized canister and back filling the canister with inert gas.

\section{DEVELOPMENT PLAN}

\subsection{Previous Planning Activities}

In 1998, Congress approved a line item construction project for the design, construction and operation of a Spent Nuclear Fuel Dry Storage Project (renamed ISFF) at the INL Site. The Project was developed to provide the core capability for SNF characterization, conditioning, packaging and storage prior to transport to the repository. In 2000 a contract was awarded for design, construction and operation of a facility to provide this capability. The design was completed for a facility to process and store three fuel types when the contract was modified to delete construction in 2006. The site contractor was tasked with development of an alternate solution for SNF conditioning and characterization given reuse of existing facilities rather than construction of a new facility. The contractor provided DOE with a feasibility level report of a method for repackaging fuel using existing facilities. The documentation developed over several years will serve as the conceptual design for this project.

\subsection{Schedule for Reaching the Major Milestones and Critical Decision Points}

Below is a Critical Path schedule. It graphically depicts work scope and major external and internal influences. The schedule lists the critical path, critical decision dates, and milestones for the Settlement Agreement, and project design and integration activities.

Scope, cost, and schedule information will be developed sufficiently to assess implementation impacts for project activities. The areas of known schedule sensitivity for the ISFF Project affecting project timing scope, cost, and schedule include:

- Regulatory Authority

- Repository Availability

- Approval of safety authorization basis documents 
- Legal agreements

- Operations (SNF drying time)

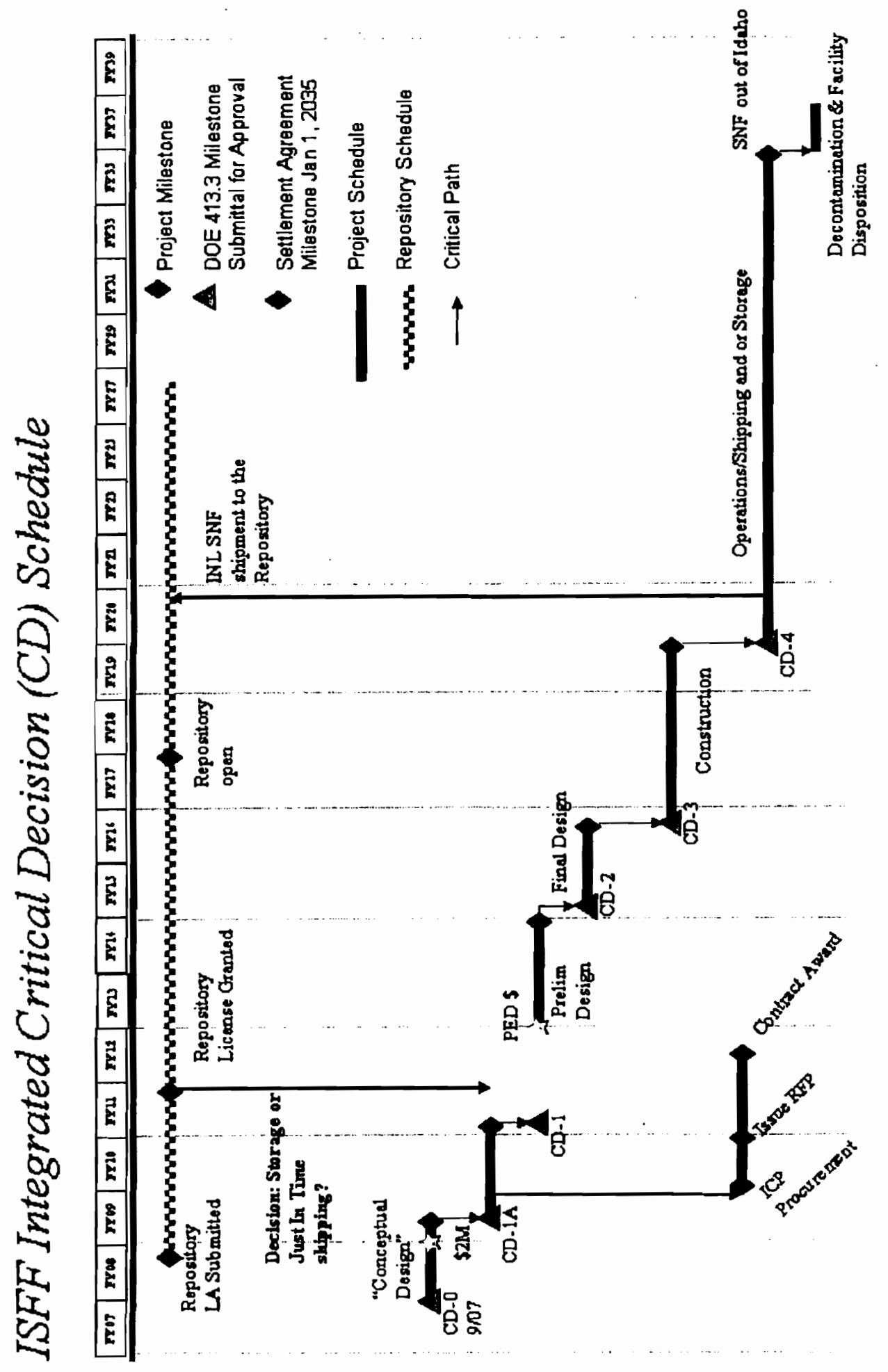




\subsection{Approach to Concept Development}

The ISFF Project activities planned after approval of CD-0 to obtain CD-1 include the compilation of existing studies conducted over the past several years to be used in the place of a Conceptual Design Report. A recommended path forward for the ISFF project, e.g. reuse of existing facilities, build new, leave decision open for bidders to propose a solution, will be presented for a CD-1A decision. Preparation of adequate documentation to support the full CD1 is subject to availability of funding in 2009. Cost ranges were developed by an external contractor bases on existing estimates and will be refined as the project and repository schedules changes.

\subsection{Possible Alternatives}

There are three basic alternatives that could be considered in the future to provide the required capability by the ISFF Project: a new facility, reuse of existing facilities and addition of new capability to old facilities. 